\title{
Responses of Irrigation and Fertilizers on the Growth and Yield of Hordeum vulgare L.
}

\author{
M. S. I. Mollah ${ }^{\mathrm{a}}$ and N. K. Paul ${ }^{\mathrm{b} *}$ \\ ${ }^{a}$ Dept. of Botany and ${ }^{b}$ Institute of Biological Sciences, Rajshahi University, Rajshahi, Bangladesh.
}

\begin{abstract}
An experiment was conducted to study the influence of soil moisture, NPK fertilizers and variety on yield and yield components of barley (Hordeum vulgare L.). Plant height, tiller number, extrusion length, spikelet number, plant weight, grain number, 100-grain weight and grain yield were observed highest in the $\mathrm{I}_{2}\left(40 \mathrm{~mm}\right.$ irrigation water) and $\mathrm{F}_{3}(120 \mathrm{~N} 75 \mathrm{P} 45 \mathrm{~K})$ treatments. $\mathrm{I}_{2}(40 \mathrm{~mm}$ irrigation water $)$ and $\mathrm{F}_{3}(120 \mathrm{~N}$ $75 \mathrm{P} 45 \mathrm{~K}$ ) treatments had the highest consumptive water use (CWU). But the highest water use efficiency (WUE) was observed in the $\mathrm{I}_{0}$ (no irrigation) and $\mathrm{F}_{3}$ treatments. Cultivar BARI-Barley-2 had the highest CWU, while cultivar BL-1 had the highest WUE.
\end{abstract}

Key words: Barley, Irrigation, Fertilizer, Grain yield, Consumptive water use, Water use efficiency.

\section{Introduction}

Barley is the world's most important cereal crop both in area and production after maize, wheat and rice, cultivated successfully in a wider range of climate from the arctic to the tropic. In Bangladesh, it is grown as rabi crop in some areas, mainly in the northern parts of the country. It ranks third after rice and wheat as supplementary food and fodder crops of Bangladesh (FAO, 2002). Barley is used for direct human consumption, animal feed, poultry feed, malt extract for manufacture of beverages, human food in the form of parched grain, pearled grain for soup, flour for bread and partly ground grain as porridge. People from Bangladesh and India prefer barley as chattu with molasses, milk or ripe mango as well as chapati made by mixing barley and wheat flour. It is a staple food in the mountainous areas of Afganistan, India and Nepal (Jain, 1988).

In spite of all these positive facts about barley, the barley cultivation trend in our country is consistently downward. The area and production of barley for the fiscal year 1991-92 were 40000 acres and 10000 tons, whereas it was 3000 acres and 1000 tons in 2004-2005, respectively (BBS, 2005). Hence, barley cultivation has to be popularized among the growers in Bangladesh (BARI, 2003-2004). But the productivity of this crop is very much poor compared to that of the other countries. Lack of well developed irrigation facilities, increased cost of irrigation and fertilizers, lack of stress or salt tolerant high yielding varieties are responsible for this. Among these, water being extremely limited in most of the barley growing area and essentially demands high efficiency in its use. Moreover, farmers of this country use different fertilizers indiscriminately without adequate information concerning actual soil requirements and this results in over or under application. A clear understanding on the use of different doses of NPK fertilizers and their utilization efficiency are pre-requisite to avoid indiscriminate use of fertilizers.

Very little work has been done in Bangladesh to develop package of improved management practices required to achieve higher yield of barley. Thus, the present experiment was carried out to find out better growth and yield components of four varieties of barley in local climatic conditions of Bangladesh.

\section{Materials and Methods}

The experiment was conducted in the experimental field of Rajshahi University campus (AEZ-11) during the period from November, 2004 to March, 2005 with four barley (Hordeum vulgare L.) varieties, namely, BARI-Barley-1, BARI Barley-2, BHL-3 and BL-1. The soil of the field was

\footnotetext{
* Corresponding author: E-mail:
} 
silty loam, having pH 7.5 as well as $35 \%$ field capacity. The characteristics of the experimental soil (initial) are given below:

A. Mechanical characteristics of soil Sand $11.24 \%$, silt $75.40 \%$ and clay $13.36 \%$.

B. Chemical composition of soil Organic carbon $1.45 \%$, total nitrogen $0.138 \%$, available P 7.25 ppm, available K 176 ppm and available S 21 ppm.

The experiment was arranged in split-split plot design with three replications. Each replicated field was divided into three main plots for irrigation treatment. Each main plot was divided into four subplots for varieties of barley. Three levels of irrigation treatments $\left(0,20\right.$ and $40 \mathrm{~mm}$ water as $\mathrm{I}_{0}, \mathrm{I}_{1}$ and $I_{2}$ respectively) were adopted at every 30 days interval for three times during the growing period. Four levels of fertilizer treatments used viz., F0 (control with no added N, P, $\mathrm{K}), \mathrm{F} 1$ (N, P and $\mathrm{K}$ used at the rate of $40,25,15 \mathrm{~kg} / \mathrm{ha}), \mathrm{F} 2$ $(\mathrm{N}, \mathrm{P}, \mathrm{K}$ at the rate of $80,50,30 \mathrm{~kg} / \mathrm{ha})$ and $\mathrm{F} 3(\mathrm{~N}, \mathrm{P}, \mathrm{K}$ at the rate of $120,75,45 \mathrm{~kg} / \mathrm{ha})$.

Necessary intercultural operations were adopted and no fungicides or insecticides were used. Six plants per treatment per variety per replication were harvested to obtain grain yield and its components. Measurements of yield were made by recording of plant height, tiller number, extrusion length, spikelet number per spike, plant weight per plant, grain number per plant, 100-grain weight and grain yield.

Soil moisture was determined gravimetrically up to $1 \mathrm{~m}$ depth of soil profile from 5 soil layers $(0-20 \mathrm{~cm}, 20-40 \mathrm{~cm}$, $40-60 \mathrm{~cm}, 60-80 \mathrm{~cm}$ and $80-100 \mathrm{~cm}$ ) before sowing of seed and at the final harvest with the help of an auger. The moisture content values were used to compute consumptive water use (CWU) according to the following formula given by Dastane (1972). Statistical analysis was carried out according to Gomez and Gomez (1984).

$\mathrm{CWU}(\mathrm{mm})=\mathrm{IR}+\mathrm{ER}+\sum_{\mathrm{i}=1}^{\mathrm{n}}(\mathrm{Mbi}-\mathrm{Mei}) / 100$ X Ai X Di Where,

$\mathrm{IR}=$ Irrigation water, $\mathrm{ER}=$ Rainfall, $\mathrm{Mbi}=$ Moisture percentage at the beginning of the season of the ith layer of the soil profile, $\mathrm{Mei}=$ Moisture percentage at the end of the season of the ith layer of the soil profile. $\mathrm{Ai}=$ Specific density of soil, i.e. apparent specific gravity of the ith layer of the soil profile, $\mathrm{Di}=$ Depth of the ith layer of the soil profile.within the root zone and $\mathrm{n}=$ Number of soil layers in the root zone D.

Table I: Analysis of variance of yield and yield components of four barley varieties as influenced by different soil moisture regimes and NPK fertilizers

\begin{tabular}{|c|c|c|c|c|c|c|c|c|c|c|c|}
\hline $\begin{array}{l}\text { Sources } \\
\text { of variation }\end{array}$ & $\mathrm{df}$ & $\begin{array}{l}\text { Plant } \\
\text { height } \\
(\mathrm{cm})\end{array}$ & $\begin{array}{c}\text { Tiller } \\
\text { number/ } \\
\text { Plant }\end{array}$ & $\begin{array}{c}\text { Extrusion } \\
\text { length } \\
(\mathrm{cm}) \\
\end{array}$ & $\begin{array}{l}\text { Spikelet } \\
\text { number } \\
\text { /plant }\end{array}$ & $\begin{array}{c}\text { Plant } \\
\text { weight/ } \\
\text { plant }(\mathrm{g})\end{array}$ & \begin{tabular}{|c} 
Grain \\
number/ \\
plant
\end{tabular} & $\begin{array}{c}\text { 100-grain } \\
\text { weight } \\
(\mathrm{g})\end{array}$ & $\begin{array}{c}\text { Grain } \\
\text { yield } \\
(\mathrm{kg} / \mathrm{ha})\end{array}$ & $\left|\begin{array}{c}\text { Consumptive } \\
\text { use of water } \\
(\mathrm{mm})\end{array}\right|$ & \begin{tabular}{|c|} 
Water \\
use efficiency \\
$(\mathrm{kh} / \mathrm{ha} / \mathrm{mm})$
\end{tabular} \\
\hline Replication & 2 & 15.3 & 5.8 & 32.6 & 23.7 & 486.0 & 20.1 & 0.4 & 19.1 & \begin{tabular}{|l|}
33.6 \\
\end{tabular} & 1.9 \\
\hline Irrigation (I) & 2 & 2.8 & 0.1 & $14.6 * *$ & 0.1 & 0.9 & 6.6 & 0.2 & $64794 * *$ & $642 * *$ & $0.8^{* *}$ \\
\hline Error (a) & 4 & 1.09 & 0.029 & 0.906 & 0.623 & 1.423 & 0.004 & 2867 & 26 & 0.027 & \\
\hline Fertilizer $(\mathrm{F})$ & 3 & $524.4 * *$ & $10.1^{* *}$ & $234.8 * *$ & 134.2 & 0.2 & $458.0 * *$ & $0.2 * *$ & $109727 * *$ & $5934 * *$ & $2.6 * *$ \\
\hline $\mathrm{IxF}$ & 6 & 1.4 & 0.1 & 2.4 & 9.9 & 0.3 & 2.5 & 0.1 & 6045 & $354.2 * *$ & $2.4 * *$ \\
\hline Error (b) & 18 & 26.74 & 0.259 & 4.527 & 4.447 & 0.616 & 17.456 & 0.015 & 10549 & 26.2 & 0.052 \\
\hline Variety (V) & 3 & $12945^{* *}$ & $21.6^{* *}$ & $424 * *$ & $1347^{* *}$ & $515^{* *}$ & $5355^{* *}$ & $5.8 * *$ & $10958295 * *$ & $85256^{* *}$ & $8.7^{* *}$ \\
\hline $\mathrm{IxV}$ & 6 & 1.1 & 0.1 & 0.8 & 1.4 & 0.3 & 2.0 & 0.1 & 3291 & 316 & $10.1 * *$ \\
\hline $\mathrm{FxV}$ & 9 & $141.5^{* *}$ & $1.6^{*}$ & $28.3 * *$ & $22.5 * *$ & 1.3 & 18.4 & 0.1 & $26600 * *$ & $2050 * *$ & $84.4 * *$ \\
\hline IxFxV & 18 & 1.9 & 0.1 & 0.4 & 2.4 & 0.3 & 2.7 & 0.1 & 3869 & $399.7 * *$ & $11.2 * *$ \\
\hline Error (c) & 72 & 12.657 & 0.080 & 0.598 & 2.343 & 5.529 & 0.009 & 8046 & 27.2 & 0.041 & \\
\hline
\end{tabular}


Water Use Efficiency (WUE): Water use efficiency was calculated by using the following formula:

WUE $\mathrm{kg} / \mathrm{ha} / \mathrm{mm})=($ Weight of grain $(\mathrm{kg} / \mathrm{ha})) /$ Consumptive use of water $(\mathrm{mm})$

\section{Results and Discussion}

Mean squares values for the grain yield and its components are presented in Table I. Irrigation effect was significant for extrusion length, grain yield, CWU and WUE. Effects of fertilizer were significant for all the yield components except spikelet number and plant weight. Varietal effect was also significant for all the yield components. Significant interaction of irrigation $\mathrm{X}$ fertilizer and irrigation $\mathrm{X}$ fertilizer $\mathrm{X}$ variety were noticed in CWU and WUE. Significant interaction of irrigation $\mathrm{X}$ variety was observed only for WUE. But interaction of fertilizer $\mathrm{X}$ variety was significant in all the yield components except plant weight and grain number per plant.

\section{Effects of irrigation}

The highest plant height was observed in the $\mathrm{I}_{2}$ treatment and the lowest was in the control (Table II). Plant height increased with the increase of irrigation. Similar result was reported in wheat by Pandit et al. (2001) and Rahman et al. (2001). Tiller number per plant was higher in the irrigated plants than in the rainfed plants. Similar results were observed by Hassan et al. (1987) in wheat. $\mathrm{I}_{2}$ treatment produced the highest number tillers per plant. This result is also corroborated with Sarker and Paul (1997) and Rahman et al.

Table II: Effect of irrigation, fertilizer and variety on the growth and yield of barley

\begin{tabular}{|c|c|c|c|c|c|c|c|c|c|c|}
\hline Treatment & $\begin{array}{l}\text { Plant } \\
\text { height } \\
(\mathrm{cm})\end{array}$ & $\begin{array}{l}\text { Tiller } \\
\text { number } \\
\text { /plant }\end{array}$ & $\begin{array}{c}\text { Extrusion } \\
\text { length } \\
(\mathrm{cm})\end{array}$ & $\begin{array}{l}\text { Spikelet } \\
\text { number/ } \\
\text { plant }\end{array}$ & $\begin{array}{c}\text { Plant } \\
\text { weight/ } \\
\text { plant (g) }\end{array}$ & $\begin{array}{c}\text { Grain } \\
\text { number/ } \\
\text { plant }\end{array}$ & $\begin{array}{c}\text { 100-grain } \\
\text { weight } \\
\text { (g) }\end{array}$ & $\begin{array}{c}\text { Grain } \\
\text { yield } \\
(\mathrm{kg} / \mathrm{ha})\end{array}$ & $\begin{array}{c}\text { Consumptive } \\
\text { use of } \\
\text { water }(\mathrm{mm})\end{array}$ & $\begin{array}{l}\text { Water use } \\
\text { efficiency } \\
(\mathrm{kh} / \mathrm{ha} / \mathrm{mm})\end{array}$ \\
\hline $\mathrm{I}_{0}(00 \mathrm{~mm})$ & 74.69 & 2.82 & 23.28 & 44.97 & 6.71 & 46.03 & 3.61 & 1665 & 150.82 & 11.02 \\
\hline $\mathrm{I}_{1}(20 \mathrm{~mm})$ & 81.77 & 3.26 & 24.31 & 47.47 & 10.51 & 52.69 & 3.75 & 1856 & 204.03 & 9.09 \\
\hline LSD $5 \%$ & 0.60 & 0.10 & 0.31 & 0.54 & 0.45 & 0.68 & 0.04 & 31 & 2.91 & 0.09 \\
\hline LSD $1 \%$ & 0.98 & 0.161 & 0.51 & 0.90 & 0.74 & 1.12 & 0.06 & 50 & 4.80 & 0.15 \\
\hline \multicolumn{11}{|l|}{ Fertilizer } \\
\hline $\mathrm{F}_{0}\left(\begin{array}{lll}0 & 00 & 00\end{array}\right)$ & 70.19 & 2.33 & 19.83 & 40.13 & 5.60 & 38.19 & 3.29 & 1237 & 205.13 & 6.23 \\
\hline $\mathrm{F}_{1}\left(\begin{array}{lll}40 & 25 & 15\end{array}\right)$ & 77.63 & 2.90 & 23.34 & 45.04 & 9.12 & 47.61 & 3.52 & 1606 & 205.74 & 8.04 \\
\hline LSD $1 \%$ & 4.16 & 0.35 & 1.45 & 1.43 & 0.55 & 2.84 & 0.18 & 76 & 4.81 & 0.21 \\
\hline \multicolumn{11}{|l|}{ Variety } \\
\hline BARI Barley-1 & 77.88 & 3.04 & 21.87 & 46.83 & 9.96 & 52.71 & 3.60 & 1789 & 206.31 & 8.95 \\
\hline BARI Barley-2 & 79.07 & 3.82 & 22.38 & 46.00 & 10.35 & 49.58 & 3.82 & 1913 & 206.84 & 8.51 \\
\hline BHL-3 & 80.17 & 3.44 & 25.33 & 50.13 & 10.12 & 50.91 & 3.76 & 1949 & 206.59 & 9.25 \\
\hline BL-1 & 86.33 & 2.54 & 27.21 & 46.21 & 10.09 & 57.47 & 3.70 & 1913 & 206.33 & 9.57 \\
\hline LSD $5 \%$ & 1.71 & 0.22 & 0.50 & 0.66 & 0.54 & 0.99 & 0.10 & 69 & 2.97 & 0.12 \\
\hline LSD 1\% & 2.24 & 0.18 & 0.49 & 0.96 & 1.17 & 1.48 & 0.06 & 56 & 4.90 & 0.19 \\
\hline
\end{tabular}


(2001) in wheat. Extrusion length increased with the increase of irrigation. The highest and the lowest extrusion length were in the $I_{2}$ and $I_{0}$ treatments, respectively. $I_{2}$ treatment had the highest number of spikelet per spike and the lowest was in the non-irrigated plants. Rahman et al. (2001) obtained similar results in wheat. The highest plant weight was in the $\mathrm{I}_{2}$ treatment and the lowest was in the control. The highest grain number per plant was in the $I_{2}$ treatment and the lowest was in the rainfed plants. $\mathrm{I}_{2}$ irrigation produced the highest 100-grain weight and the grain yield and the lowest was in the control. These findings are corroborated with Rahman and Paul (1998) and Rahman et al. (2001) in wheat. Irrigated plants had higher CWU than the rainfed plants. The highest CWU (264 mm) was in the $\mathrm{I}_{2}$ treatment. Similar observation was reported in wheat by El-Rab et al (1988). They reported that CWU of wheat arrived its maximum value when six irrigations were imposed and decreasing number of irrigation decreased CWU. The highest WUE was in the $I_{0}$ treatment followed by the $I_{1}$ and $I_{2}$ treatments. Similar findings were reported in wheat by Rahman and Islam (1991). Lower WUE with higher soil moisture status was due to proportionately more increase in evapotranspiration than the increase in seed yield.

\section{Effects of fertilizer}

Plant height was increased with increasing levels of fertilizers. The highest plant height was in the $F_{3}$ fertilized plants and the lowest was in no fertilizer application (Table II). Similar result was noticed in barley by Shim et al. (1988) and Alam (2003). The increase in plant height by increasing fertilizer rate might be attributed to the increase in internode length since the number of internode is greatly influenced by the genetic make up of the plant as stated by Khalifa (1970). The fertilized plants had comparatively higher tiller number per plant than that of the control. Increased fertilizer level generally increased number of total tillers per plant. $F_{3}$ treatment produced the highest number of tillers. This result is in agreement with Garcia et al. (1999) and Alam (2003) in barley. Photosynthesis and other metabolic activities were hindered by the water stressed condition and as a result, plants did not have enough assimilates to afford the potential growth of all the produced tillers and thereby the number of tillers was reduced due to water stress. Extrusion length increased with increasing fertilizer levels. $\mathrm{F}_{3}$ and $\mathrm{F}_{0}$ treatments produced the highest and the lowest extrusion length, respectively. The highest spikelet number was in the $\mathrm{F}_{3}$ treatment and the lowest was in the zero fertilizer treatment. These results are in agreement with the findings of Shim et al. (1988) and Alam (2003) in barley. $\mathrm{F}_{3}$ treatment had the highest grain number per plant, whereas the lowest was in the control. The highest and the lowest 100-grain weight were in the $\mathrm{F}_{3}$ and $\mathrm{F}_{0}$ treatments, respectively. Fertilizer produced heavy grains and thus the 100-grain weight was increased in the fertilized plants. Almost similar result was reported in barley by Dudas (1994), Ibrahim and Azer (2001) and Alam (2003).Increased fertilizer dose increased grain yield. The highest grain yield $(2461 \mathrm{~kg} / \mathrm{ha})$ was in the $\mathrm{F}_{3}$ treatment and the lowest $(1237 \mathrm{~kg} / \mathrm{ha})$ was in no fertilizer application. Similar results were reported in barley by Alam et al. (2005) and Salam et al. (2006). CWU was to increase with the increase of fertilizer level. $\mathrm{F}_{3}$ treatment had the highest $\mathrm{CWU}$ followed by the $\mathrm{F}_{2}, \mathrm{~F}_{1}$ and $\mathrm{F}_{0}$ treatments. F3 treatment had the highest WUE followed by the $F_{2}, F_{1}$ and $F_{0}$ treatments (Table II).

\section{Effect of variety}

The highest plant height $(86.32 \mathrm{~cm})$ was in BL-1 followed by BHL-3, BARI Barley-2 and BARI Barley-1 Table II). BARI Barley-2 had the highest tiller number (3.82) followed by BHL-3, BARI Barley-1 and BL-1. BL-1 had the highest extrusion length. The highest spikelet number (50.13) was in BHL-3. The highest plant weight (10.35 g) was in BARI Barley-2. BL-1 had the highest grain number per plant (57.47). The highest 100-grain weight $(3.82 \mathrm{~g})$ was in BARI Barley-2. BHL-3 had the highest grain yield (1949 kg/ha) followed by BARI Barley-2, BHL-3 and BARI Barley-1. Ahmed et al. (2006) reported that BARI Barley-1 gave the highest grain yield, whereas the lowest grain yield was obtained from the local variety with delayed sowing. BARI Barley-2 had the highest CWU followed by BHL-3 and the lowest was in BL-1followed by BARI Barley-1. BL-1 had the highest WUE among the varieties but the lowest was in BARI Barley-2 followed by BARI Barley-1.

In this study, yield and yield components of four barley varieties were observed highest in the highest level of irrigation 
(40 mm irrigation water) and fertilizer (N120 P75 K45) than the control. So, proper crop growth is very much dependent on the availability of adequate amount of soil moisture and fertilizer. If $40 \mathrm{~mm}$ irrigation and N120 P75 K45 fertilizer levels are maintained properly, better growth and development and higher grain yield of barley can be achieved.

\section{References}

Ahmed S., Islam M. S., Salam A. and Hossain M. F. (2006). Effect of sowing time on the yield attributes of barley in high barind tract. Bangladesh J. Agril. Res. 31(2): 231-239.

Alam M. Z. (2003). Influence of planting dates and nitrogen levels on growth, grain yield and nitrogen utilization of barley (Hordeum vulgare L). Ph.D. Thesis. Department of Botany, Rajshahi University.

Alam M. Z., Haider S. A. and Paul N. K. (2005). Effects of sowing time and nitrogen fertilizer on barley (Hordeum vulgare L.). Bangladesh J. Bot. 34(1):27-30.

BARI (Bangladesh Agricultural Research Institute). 20032004. Barley improvement. Annual Research Report. Plant Breeding Division. Joydebpur, Gazipur. p. 1.

BBS. (2005). Statistical Yearbook of Bangladesh, Bangladesh Bureau of Statistics, Planning Division, Ministry of Planning, Government of People's Republic of Bangladesh. Agriculture: Crops, Livestock, Forestry and Fishery. 25: 141.

Dastane N. G. (1972). Practical Manual for Water Use Research in Agriculture. Navabharat Prokashan, Poona, India.

Dudas F. (1994). Grain quality of barley cv. Perun under different cultivation practices. Acta Universitatis Agriculturae, Facultas Agronomica. 42(1/2): 149-159.

El-Rab G. M. G., Ainer N. G. and Eid H. M. (1988). Water stress in relation to yield of wheat and some water relations in wheat Egypt. J. Soil Sci.28: 433-445.
FAO (2002). FAOSTAT: Statistics database (Online) (Subset Production within Agriculture database) Available at http: 11apps. fao.org.

Garcia del Moral, L. F., Morena I. de la and Ramos, J.M. (1999) Effects of nitrogen and foliar sulphur interaction on grain yield and yield components in barley. $J$. Agron. \& Crop Sci. 183(4):287-295.

Gomez K. A. and Gomez A. A. (1984) Statistical Procedure for Agricultural Research. John Wiley and Sons. New York.

Hassan U. A., Ogunlela V. B. and Sinha T. D. (1987) Agronomic performance of wheat (Triticum aestivum L.) as influenced by moisture stress at various growth stages and seeding rate. J. Agron. \& Crop Sci. 3: 175180 .

Ibrahim K. I. M. and Azer S.A. (2001). Effect of N-fertilization levels and plant densities on the relative importance of yield contributors in some barley mutant lines. Ann. Agril. Sci. (Cairo). 46(2): 631-641.

Khalifa M. A. (1970). Effect of the application of nitrogen, phosphorus and potassium fertilizers on yield and other characters of corn (Zea mays L.). M.Sc. Thesis. Fac. Agric. Cairo University.

Pandit J. C., Kamal A. M. A., Hossain S. M. A. and Ali M. I. (2001). Effect of variety and irrigation on yield and protein content of wheat. Bangladesh J. Crop Sci. 12: 87-95.

Rahman M. S. and Paul N. K. (1998). Effect of soil moisture regimes on physiological characters and yield of wheat cultivars. J. Bio. Sci. 6: 5-10.

Rahman M. S., Sarker A. M., Islam M. S. and Paul N. K. (2001) Effect of soil moisture on grain yield of wheat (Triticum aestivum L.) cultivars. Environment \& Ecol. 19: 304-308.

Rahman S. M. and Islam A. (1991). Yield and water relations of wheat as influenced by irrigation and depth of tillage. Irrig. Sci. 12: 67-71. 
Salam M. A., Islam M. S., Rahman M. A., Bari M. S. and Assaduzzaman M. (2006). Response of barley to sowing time and nitrogen rate in High Barind Tract of Bangladesh. J. Bangladesh Soc. Agric. Sci. Technol. 3: 149-152.

Sarker A. M. and Paul N. K. (1997). Effect of soil moisture on growth, yield and quality of wheat. Rajshahi Univ. Stud. 25: 247-256.
Shim J. W., Lee H. S. and Choi K. J. (1988). Effect of soil acidity and nitrogen fertilization on the growth and yield of barley cultivars. Korean J. Crop Sci. 33: 12-22

Received: August 24, 2010;

Accepted : January 13, 2010 